\title{
COMO REFERENCIAR OS ARTIGOS DESTA EDIÇÃO
}

Autor [SOBRENOME, Nome]. Título do artigo. Espaço Ameríndio, Porto Alegre, v. 10, n. 1, p. [intervalo de páginas], jan./jun. 2016. Disponível em: [endereço eletrônico]. Acesso em: [dia/mês/ano].

Exemplo:

FERNANDES, Edimar Antonio. Novos atores em cena na Antropologia. Espaço Ameríndio, Porto Alegre, v. 10, n. 1, p. 254-269, jan./jun. 2016. Disponível em: http://www.seer.ufrgs.br/index.php/EspacoAmerindio/editor /proofGalley/9238/8257. Acesso em: 30 jun. 2016. 